\title{
INVESTIGATION OF WEATHERING DAMAGE ON STONE MONUMENTS
}

\author{
Bernd Jürgen Fitzner \\ RWTH Aachen University - Germany \\ fitzner@geol.rwth-aachen.de
}

\begin{abstract}
Stone monuments represent an important part of our world's cultural heritage. The awareness of increasing stone damage on monuments and the danger of irretrievable loss of cultural heritage have resulted in great efforts worldwide for sustainable monument preservation. A precise damage diagnosis with the comprehensive characterization, interpretation and rating of stone damage represents the basis for effective and economic monument preservation measures. The experienced methodological approach to the assessment of stone damage combines in situ investigation and laboratory studies. The monument mapping method is presented as an established nondestructive procedure for in situ studies on stone damage. It can be applied to all stone types and to all kinds of stone monuments. The use of weathering forms, damage categories and damage indices for the registration, documentation, quantitative evaluation and rating of stone damage is explained. Furthermore, complementary in situ measurements are discussed. A wide range of analytical procedures and weathering simulation tests contribute to modern damage diagnosis on stone monuments.
\end{abstract}

Keywords: damage, stone, monuments

Resumo: INVESTIGAÇÃO SOBRE DANOS DO INTEMPERISMO PARA MONUMENTOS EM PEDRA. Os monumentos em pedra representam uma parte importante do patrimônio cultural do mundo. A consciência do aumento dos danos causados ao material pétreo nesses monumentos e o perigo de perda irrecuperável desse património resultaram em grandes esforços a nível mundial para a preservação sustentável desses monumentos. Um diagnóstico preciso de danos com a caracterização, interpretação e avaliação abrangentes desses danos causados às pedras representa a base para a adoção de medidas de conservação eficazes e econômicas. A abordagem metodológica a ser adotada para a avaliação desses danos deve combinar a investigação in situ e estudos laboratoriais. Nessa abordagem o mapeamento de monumentos é apresentado como um procedimento não destrutivo estabelecido para os estudos in situ sobre danos causados às pedras, podendo ser aplicado a todos os tipos de pedra e a todos os tipos de monumentos construídos com a pedra. Nesse trabalho, o uso de formas de intemperismo, categorias de danos e índices de danos para o registro, documentação, avaliação quantitativa e classificação de danos para a pedra é explicado. Além disso, discutem-se medidas complementares a serem adotadas in situ. Uma ampla gama de procedimentos analíticos e testes de simulação de meteorização contribuem para o diagnóstico de danos modernos em monumentos construídos em pedra.

Palavras Chave: dano, pedra, monumentos

\section{INTRODUCTION}

The alarming increase of weathering damage on natural stone monuments and the danger, that in near future a major part of built cultural heritage could be partially or completely destroyed, requires immediate measures in order of sustainable monument preservation (Figures1-4).

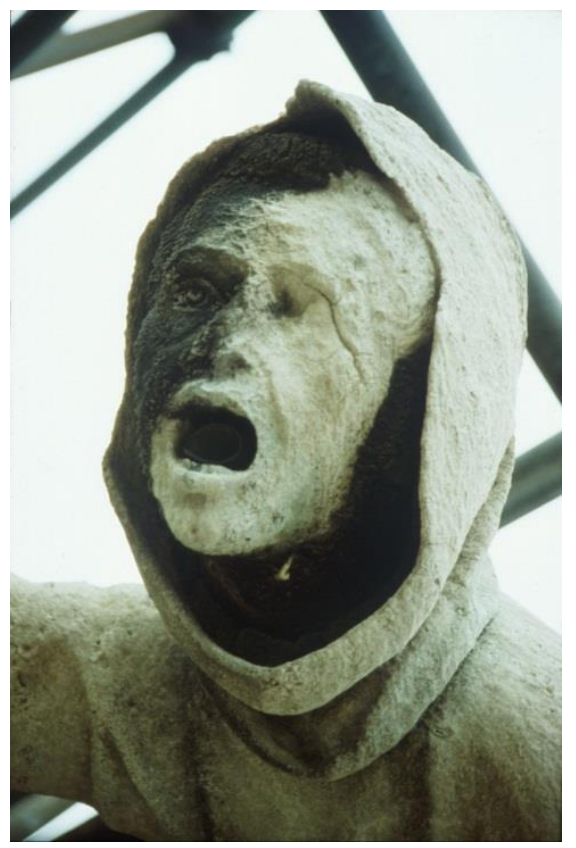

Figure 1. Gargoyle, Naumburg Cathedral (Germany).

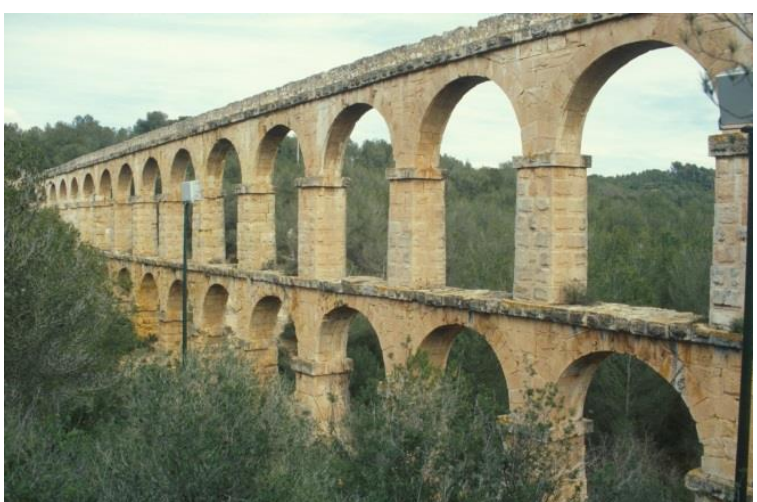

Figure 2. Aqueduct near Tarragona (Spain).

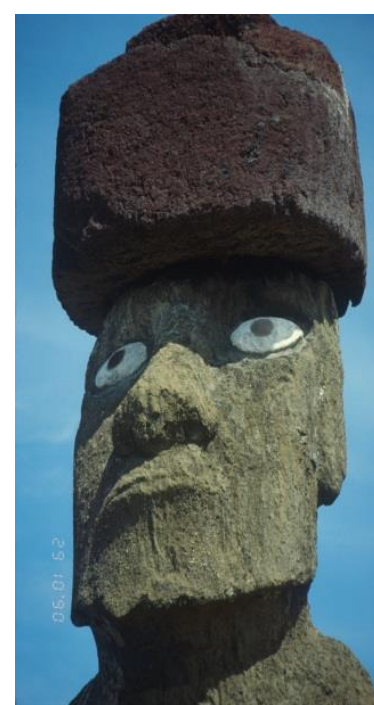

Figure 3. Moai, Easter Island (Chile). 


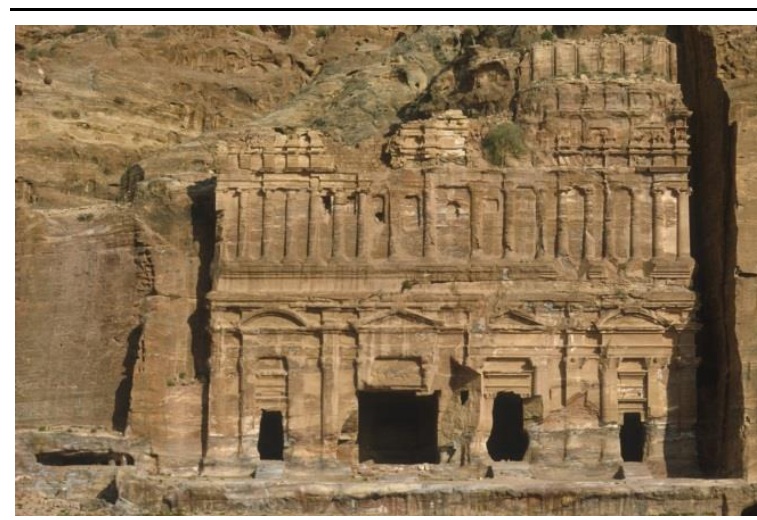

Figure 4. Palace Tomb, Petra (Jordan).

Profound knowledge of the material properties and the weathering behaviour of the natural stones used is necessary, as well as knowledge of weathering factors and weathering processes which initiate and control this weathering behaviour. High level of scientific knowledge is an important basis for effective and economic preservation measures. The well-accepted systematic approach to sustainable monument preservation can be subdivided into the three interdependent parts of anamnesis, diagnosis and therapeutical steps (Figure 5).

\begin{tabular}{|c|c|c|c|c|}
\hline \multicolumn{5}{|c|}{$\begin{array}{l}\text { APPROACH TO SUSTAINABLE PRESERVATION } \\
\text { OF STONE MONUMENTS }\end{array}$} \\
\hline$\downarrow$ & \multirow{4}{*}{$\rightarrow$} & $\downarrow$ & \multirow{4}{*}{$\rightarrow$} & $\downarrow$ \\
\hline ANAMNESIS & & DIAGNOSIS & & THERAPY \\
\hline $\begin{array}{c}\text { Object } \\
\text { identification }\end{array}$ & & \multirow{2}{*}{$\begin{array}{c}\text { Stone materials } \\
\text { and their } \\
\text { properties }\end{array}$} & & \multirow{3}{*}{$\begin{array}{c}\text { Conception, } \\
\text { calculation, } \\
\text { test-application } \\
\text { of preservation } \\
\text { measures }\end{array}$} \\
\hline $\begin{array}{l}\text { Location of the } \\
\text { object }\end{array}$ & & & & \\
\hline \multirow{2}{*}{$\begin{array}{l}\text { Description of } \\
\text { the object }\end{array}$} & & $\begin{array}{c}\text { State of } \\
\text { deterioration }\end{array}$ & & \\
\hline & & $\begin{array}{l}\text { Factors and } \\
\text { processes }\end{array}$ & & \multirow{2}{*}{$\begin{array}{c}\text { Implementation } \\
\text { of preservation } \\
\text { measures }\end{array}$} \\
\hline Art history & & $\begin{array}{c}\text { of stone } \\
\text { deterioration }\end{array}$ & & \\
\hline $\begin{array}{c}\text { Construction } \\
\text { history }\end{array}$ & & \multirow{2}{*}{$\begin{array}{l}\text { Progression of } \\
\text { stone } \\
\text { deterioration }\end{array}$} & & Quality control \\
\hline $\begin{array}{l}\text { Restoration } \\
\text { history }\end{array}$ & & & & \multirow{2}{*}{$\begin{array}{l}\text { Monitoring and } \\
\text { maintenance }\end{array}$} \\
\hline Case history & & Rating of damage & & \\
\hline$\uparrow$ & & $\uparrow$ & & $\uparrow$ \\
\hline \multicolumn{5}{|c|}{ DOCUMENTATION } \\
\hline
\end{tabular}

Figure 5. Anamnesis, diagnosis and therapeutical steps.

The anamnesis is to acquire, compile and evaluate all information, data and documents concerning the monument and its history. A comprehensive anamnesis has to consider all aspects like monument identification, location, arthistorical portrayal, case history and environment. The information provided by the anamnesis contributes to the understanding of the monument situation and the state of damage.
The anamnesis is consequently followed by the diagnosis. The overall aim of diagnosis is analysis, quantification, interpretation and rating of stone deterioration and stone damage considering weathering factors, weathering processes and weathering characteristics as well as stone types, monument characteristics and time factor. The optimization of diagnostical procedures is an additional scientific objective. Profound diagnosis represents the basis for sustainable monument preservation.

Particular aims of scientific diagnosis are:

- characterization of stone materials,

- characterization and quantification of stone alteration,

- characterization and quantification of weathering characteristics - weathering forms, weathering profiles, weathering products,

- detection of non-visible stone damage,

- information on weathering factors

- information on weathering processes,

- characterization and quantification of weathering progression / weathering rates,

- quantitative rating of stone damage,

- rating of stone quality, selection of durable stone materials,

- damage prognosis, risk prognosis,

- information on need / urgency of preservation measures,

- recommendation of appropriate preservation measures.

Subsequent to preservation measures, diagnostical activities facilitate the control / certification of the preservation measures and the prevention of new damage, long-term monitoring and maintenance of monuments.

The systematic investigation of stone deterioration at monuments must consider different scales of stone deterioration. Visible and non-visible stone deterioration can be distinguished. According to Viles et al. (1997), a subdivision can be made into nanoscale $(<\mathrm{mm})$, microscale $(\mathrm{mm}$ to $\mathrm{cm})$, mesoscale ( $\mathrm{cm}$ to $\mathrm{m}$ ) and macroscale (whole facades or buildings) of stone deterioration (Figure 6). The nanoscale corresponds to non-visible stone deterioration, whereas the microscale, mesoscale and macroscale refer to visible stone deterioration. Each scale is assessed by appropriate parameters and investigation methods for the evaluation of stone deterioration. For the comprehensive evaluation of stone deterioration, the 
interdisciplinary cooperation of scientists from different fields - geosciences, material sciences, chemistry, physics, microbiology, engineers and architects is required.

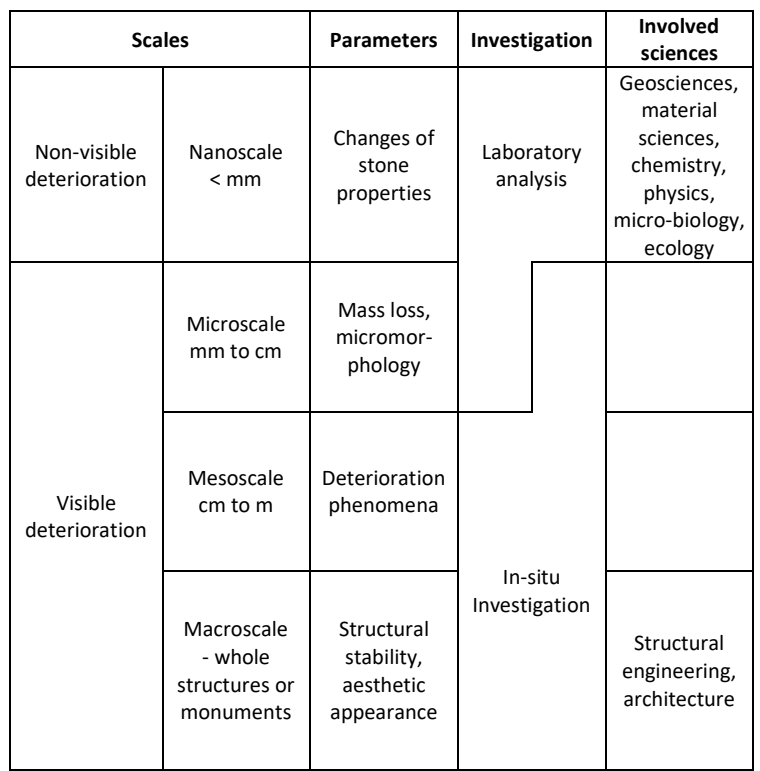

Figure 6. Scales of stone deterioration, modified from Viles et. al. (1997).

The diagnosis methodology presented, which combines in situ investigation, laboratory analysis and weathering simulation / outdoor exposure, is focussed on nanoscale, microscale and mesoscale of stone deterioration. In situ investigation is targeted to information on stone deterioration in the range of mesoscale to microscale. Laboratory analyses provide information on stone deterioration at microscale and nanoscale. Weathering simulation procedures and outdoor exposure tests in combination with laboratory analysis and in situ investigation further contributes to the evaluation of stone deterioration at mesoscale, microscale and nanoscale. Evaluation of stone deterioration at macroscale will be the task of structural engineers and architects.

The consequent application of in situ investigation, laboratory studies and weathering simulation and the joint evaluation of results contribute essentially to comprehensive and reliable damage diagnosis for stone monuments.

Based on anamnesis and diagnosis, effective and economic therapeutical steps can be proposed and calculated. Test-application should precede the final execution of preservation measures. Important therapeutical and preventive preservation measures such as safeguarding, cleaning, desalination, stone repair, stone replacement, surface protection, sheltering or relocation of stone objects are presented in Figure 7. The effectiveness of preservation measures should be monitored in the frame of long-term monument observation.

\begin{tabular}{|c|c|}
\hline \multicolumn{2}{|c|}{$\begin{array}{l}\text { CONCEPTION, CALCULATION, TEST-APPLICATION } \\
\text { AND EXECUTION OF PRESERVATION MEASURES }\end{array}$} \\
\hline \multicolumn{2}{|c|}{$\begin{array}{l}\text { IMMEDIATE SAFEGUARDING MEASURES } \\
\text { Refixing of loose stone fragments, preconsolidation }\end{array}$} \\
\hline \multicolumn{2}{|c|}{$\begin{array}{c}\text { Washing, mechanical or chemical cleaning, biological cleaning, } \\
\text { laser cleaning }\end{array}$} \\
\hline \multicolumn{2}{|c|}{ DESALINATION } \\
\hline \multicolumn{2}{|c|}{ STONE REPAIR } \\
\hline \multicolumn{2}{|c|}{ STONE REPLACEMENT } \\
\hline \multicolumn{2}{|c|}{ SURFACE PROTECTION } \\
\hline \multicolumn{2}{|c|}{$\begin{array}{c}\text { CONSOLIDATION } \\
\text { Limewater technique, organic polymers, alkoxysilanes, epoxy } \\
\text { resins, acrylics, acrylic total penetration }\end{array}$} \\
\hline $\begin{array}{c}\text { SURFACE COATINGS } \\
\text { Rendering, surface-grouting, paint }\end{array}$ & $\begin{array}{l}\text { HYDROPHOBATION } \\
\text { Silanes, siloxanes, silicon }\end{array}$ \\
\hline \multicolumn{2}{|c|}{ TREATMENT WITH REACTION INHIBITORS } \\
\hline \multicolumn{2}{|c|}{ CONTROL OF BIOLOGICAL COLONIZATION } \\
\hline \multicolumn{2}{|c|}{$\begin{array}{c}\text { STRUCTURAL REINFORCEMENT } \\
\text { Grout injections, glues, dowels, repointings }\end{array}$} \\
\hline \multicolumn{2}{|c|}{ SHELTERING } \\
\hline \multicolumn{2}{|c|}{ RELOCATION OF STONE ELEMENTS TO INDOOR AREA } \\
\hline $\begin{array}{r}\text { CONTROL/CERTIFICATION, LOI } \\
\text { MAINTENANCE OF STOI }\end{array}$ & $\begin{array}{l}\text { TERM OBSERVATION } \\
\text { MONUMENTS }\end{array}$ \\
\hline
\end{tabular}

Figure 7. Monument preservation measures (ASHURST, J. \& ASHURST, N. 1998; CROCI, 1998; PRICE, 1990; PETZET, 1999).

\section{IN SITU INVESTIGATION}

In situ investigation comprises monument mapping, in situ measurements and sampling. Monument mapping is applied for the precise registration, documentation and evaluation of lithotypes and deterioration phenomena. In situ measurements can provide complementary quantitative information for characterization of lithotypes and state of deterioration. Based on results obtained from monument mapping, in situ measurements can be well-directed. Monument mapping and in situ measurements contribute essentially to the optimization of sampling for laboratory analysis.

\subsection{Monument mapping}

Many stone monuments have suffered serious damage as a consequence of natural weathering processes, pollution, insufficient maintenance, utilization, use of sensitive materials or inappropriate conservation. Profound diagnosis is required for characterization, interpretation and rating of stone deterioration and for planning and execution of effective and economic preservation measures. Precise information on factors, processes and characteristics of stone deterioration would be optimal for damage diagnosis and for the solution of scientific and practical problems. Experience has shown that the investigation of factors and processes of stone deterioration is difficult and timeand cost-consuming. Very often, results are insufficient and unsatisfactory. Investigation on deterioration characteristics - in particular deterioration phenomena, deterioration profiles and 
deterioration products - has turned out as most promising approach. Knowledge of the deterioration characteristics allows to deduce information on factors and processes of stone deterioration (FITZNER et al. 1997; HEINRICHS \& FITZNER, 1997) and to recommend suitable complementary studies.

The monument mapping method has been developed as a non-destructive procedure for the detailed registration, documentation and evaluation of lithotypes and deterioration phenomena (FITZNER \& HEINRICHS, 1998, 2002).

Monument mapping can be applied to all stone types and to all kinds of stone objects ranging from sculptures to facades or entire monuments. The mapping method meets great international acceptance and is approved as an experienced method contributing essentially to:

- improvement of scientific knowledge of stone deterioration,

- profound damage diagnosis,

- risk prognosis,

- risk management,

- sustainable monument preservation.

Monument mapping represents the only method which allows to describe and evaluate complete stone structures precisely and reproducibly according to type and distribution of lithotypes and deterioration phenomena. For detailed monument mapping accessibility of the investigation areas is necessary. Two modes of monument mapping can be distinguished: lithological mapping and mapping of weathering forms. The term "weathering forms" is synonymous with "deterioration phenomena" and corresponds to visible stone deterioration at mesoscale (cm to $\mathrm{m}$ ).

Plans of the investigation areas and classification schemes of lithotypes and weathering forms are required for monument mapping. Based on these classification schemes, in the course of monument mapping all lithotypes and weathering forms are registered and are recorded in plans. Computerprogrammes are used for the processing, illustration and evaluation of mapping information.

While weathering forms are used for the description of deterioration phenomena according to type and intensity, damage categories and damage indices have been established as a tool for the rating of damage and as a contribution to risk prognosis and risk management (Figure 8). On the basis of defined schemes, all weathering forms taking into consideration their range of intensity get related to damage categories. Six damage categories have been defined: 0 - no visible damage,
1 - very slight damage, 2 - slight damage, 3 moderate damage, 4 - severe damage, 5 - very severe damage. The damage categories are illustrated in maps and are evaluated quantitatively. Based on the quantitative evaluation of damage categories, damage indices are calculated for conclusive quantification and rating of damage. In this way, damage indices complete a consistent and convincing approach to the characterization, evaluation, quantification and rating of visible stone damage.

\begin{tabular}{|c|c|}
\hline WEATHERING FORMS & $\begin{array}{l}\text { Detailed description of individual } \\
\text { weathering phenomena with } \\
\text { quantification of intensities }\end{array}$ \\
\hline \multicolumn{2}{|c|}{$\begin{array}{c}\downarrow \\
\text { Definition of damage categories, relating of weathering forms to } \\
\text { damage categories } \\
\downarrow\end{array}$} \\
\hline DAMAGE CATEGORIES & $\begin{array}{l}\text { Rating of individual weathering } \\
\text { damage }\end{array}$ \\
\hline \multicolumn{2}{|c|}{$\begin{array}{c}\downarrow \\
\text { Definition of damage indices, calculation from proportion of } \\
\text { damage categories } \\
\downarrow\end{array}$} \\
\hline DAMAGE INDICES & $\begin{array}{l}\text { Conclusive quantification and rating of } \\
\text { damage }\end{array}$ \\
\hline
\end{tabular}

Figure 8. Weathering forms, damage categories and damage indices.

The mode of lithological mapping comprises survey, identification, petrographical characterization and registration of all lithotypes. Well-established petrographical classification schemes are used for the description of the lithotypes. Original stone material and stone material of former restoration phases should be distinguished. Based on the classification scheme of lithotypes, the investigation area is mapped stone by stone. So the distribution of lithotypes is documented. This is important for correlations between lithotypes and state of deterioration as well as for well-directed sampling. The lithotypes are evaluated quantitatively and the distribution of the lithotypes is illustrated in lithological maps.

Weathering forms on stone monuments represent the visible results of weathering processes which are initiated and controlled by interacting weathering factors. The term "weathering forms" is used for visible stone deterioration at mesoscale $1 \mathrm{~cm}$ to $m$ ). Examples of weathering forms are shown in Figures $(9-12)$.

The objective and reproducible description, registration and documentation of weathering forms require a precise classification scheme of weathering forms. Such a classification scheme has been developed, based on investigation at numerous monuments world-wide considering different stone types and environments. 


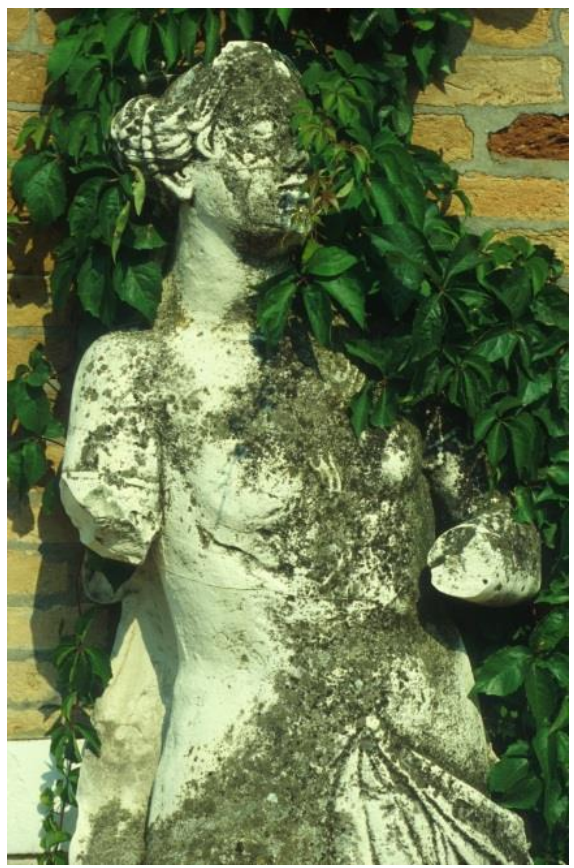

Figure 9. Biological colonization, sculpture / Torcello (Italy).

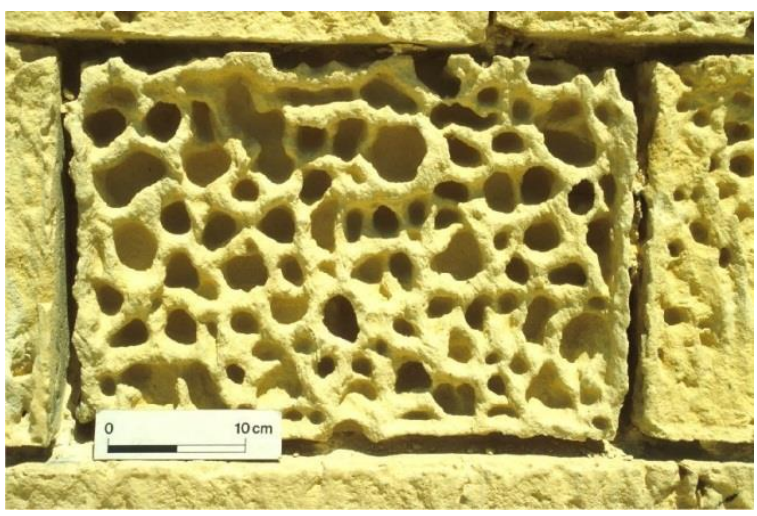

Figure 10. Alveolar weathering, Citadel / Victoria - Gozo (Malta).

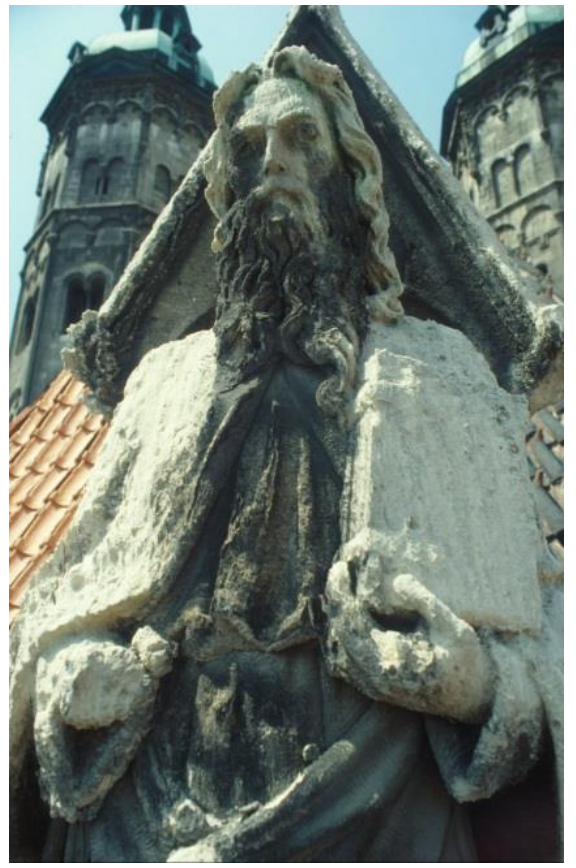

Figure 11. Crust, sculpture / Naumburg Cathedral (Germany).

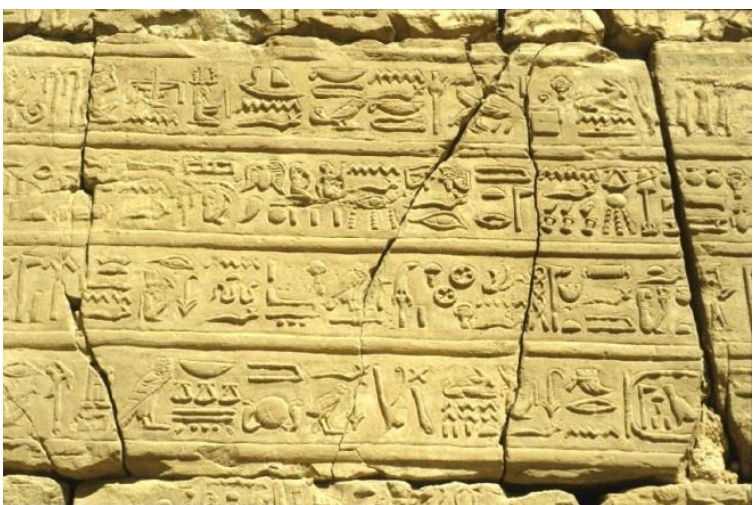

Figure 12. Fissures, Karnak Temple / Luxor (Egypt).

The classification scheme of weathering forms and an updated version with definitions, parameters for intensity classification and photo-atlas are presented in (FITZNER et al. 1995; FITZNER \& HEINRICHS, 2002; 2004). The classification scheme has met great international acceptance. It shows a hierarchic structure. The uppermost level (I) comprises four groups of weathering forms:

- group 1 - loss of stone material,

- group 2 - discoloration / deposits,

- group 3 - detachment,

- group 4 - fissures / deformation.

In level II each group is subdivided into main weathering forms. In level III several main weathering forms are further specified by means of individual weathering forms. In the most differentiated level IV, the individual weathering forms are further differentiated according to intensities.

The classification scheme of weathering forms can still be specified considering particular stone types or monument assemblies. Specification concerns the definition of individual weathering forms and the suitable intensity classification of the weathering forms. The intensity classification should be adjusted to the range of intensities surveyed at the monuments under investigation.

All weathering forms registered in the course of monument mapping are illustrated in maps and are evaluated quantitatively by means of computersupported data processing. Illustration of weathering forms in maps according to the four groups of weathering forms "loss of stone material", "discoloration / deposits", "detachment" and "fissures / deformation" has turned out as a very suitable mode of illustration.

Illustration and quantitative evaluation of weathering forms provide information on:

- characteristic weathering forms, 
- interrelations between weathering forms, especially as concerns loss of stone material, current detachment of stone material and deposits,

- distribution / zonation of weathering forms,

- chronological sequences of weathering forms,

- weathering progression, weathering rates,

- stone durability, susceptibility to weathering,

- causes and processes of stone deterioration.

In Figures $(13-15)$ the rock-cut Tomb No. 778 in Petra / Jordan, a map of its weathering forms of group 1 "loss of stone material" and a map of its average weathering rates derived from the evaluation of these weathering forms are shown.

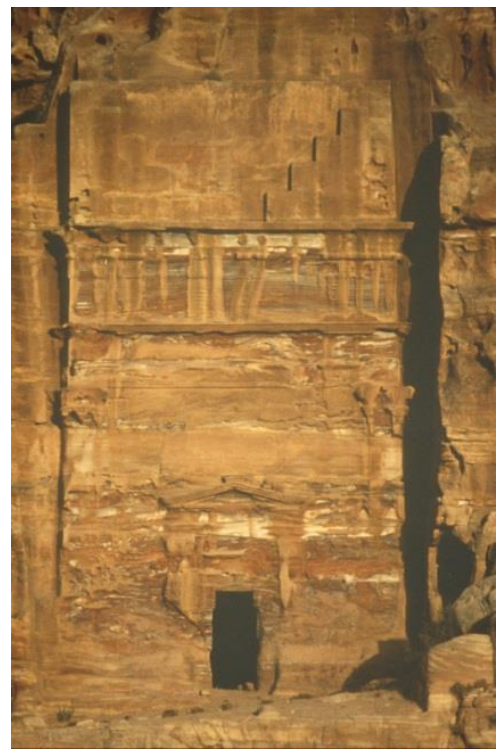

Figure 13. Tomb No. 778, Petra (Jordan).

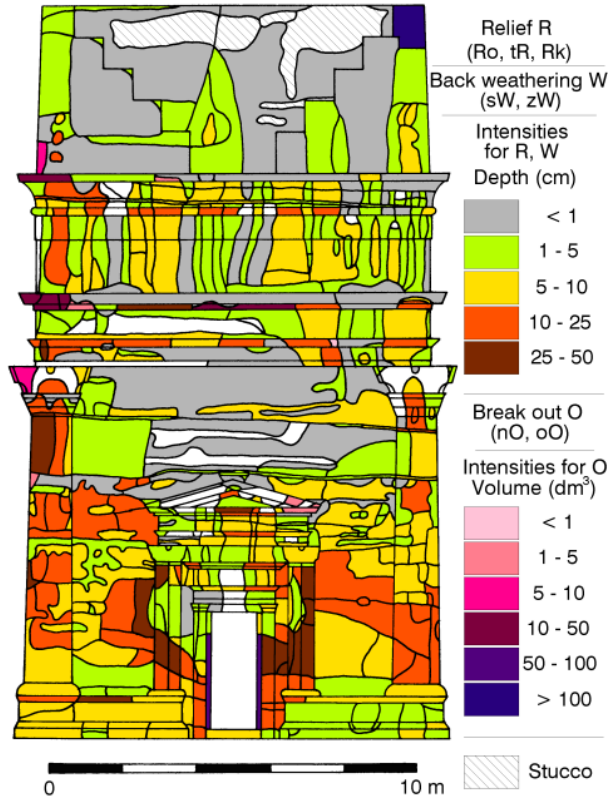

Figure 14. Map of weathering forms - "loss of stone material". Tomb No. 778.

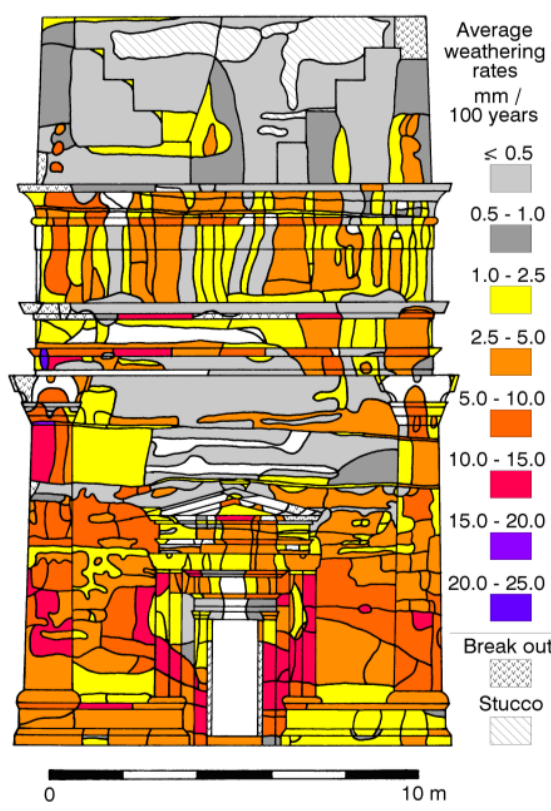

Figure 15. Average weathering rates. Tomb No. 778, Petra (Jordan).

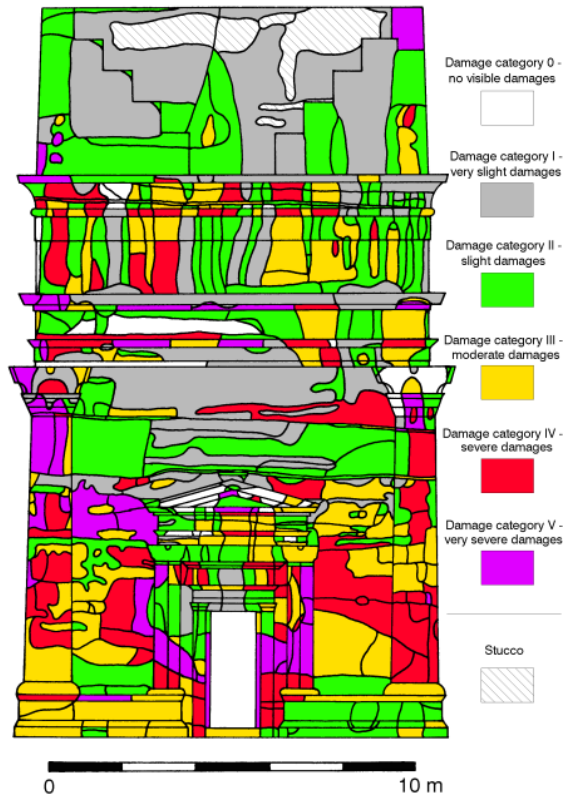

Figure 16. ap of damage categories. Tomb No. 778, Petra (Jordan).

The information obtained from the evaluation of weathering forms can be further specified considering selected lithotypes and monument exposition characteristics like location, geometry or orientation. With respect to transferability of results, elaboration of characteristic weathering forms in dependence on lithotypes, monument characteristics, environment and time represents an important step of evaluation. This also contributes to the development of weathering models.

Damage categories have been established for the comparative rating of individual damage (FITZNER \& HEINRICHS, 2002; FITZNER et al. 2002). Six damage categories have been defined: 0 - no visible damage, 
I - very slight damage, II - slight damage, III moderate damage, IV - severe damage, V - very severe damage. Based on defined schemes, all weathering forms are related to damage categories. The correlation schemes "weathering forms damage categories" must consider weathering forms and their intensities, proportion "degradated stone parts - total dimension of the stone element", function of the structural elements as well as the historical and artistical value of the stone elements. An appropriate correlation scheme "weathering forms - damage categories" requires cooperation of all experts involved in monument diagnosis and monument preservation.

Damage indices are calculated from proportion of damage categories (FITZNER \& HEINRICHS, 2002; FITZNER et al. 2002). A linear and a progressive damage index has been defined. The damage indices range from 0 to 5.0. According to the calculation modes, the linear damage index corresponds to average damage category, whereas the progressive damage index emphasises proportion of higher damage categories. Following relation arises: progressive damage index $\geq$ linear damage index.

The use of damage indices ensures the quantification and rating of stone damage for entire monuments or single structures. Damage indices allow comparison and ranking of different monuments or parts of monuments. The illustration of damage categories in maps and the quantitative evaluation of damage categories with the determination of damage indices are presented again for the Tomb No. 778 in Petra / Jordan (Figures 13, 16 and 17).

The use of damage indices contributes essentially to rating and comparison of stone materials regarding their susceptibility to degradation. It enhances risk estimation and contributes to risk management. Damage indices point out need and urgency of intervention. Damage categories locate those parts of a monument which intervention has to focus on. Weathering forms have to be considered for deduction of appropriate types of preservation measures. Damage categories and especially damage indices represent very practical tools for reliable judgement/certification of preservation measures. For the regular re-evaluation of monuments in the frame of long-term survey and maintenance the consequent application of weathering forms, damage categories and damage indices is advisable.

The use of weathering forms, damage categories and damage indices can be considered as an advanced approach and as an essential contribution to well-founded damage diagnosis at stone monuments and to sustainable monument preservation. The consistent strategy of linking weathering forms with damage categories and damage indices is well-addressed and recommended to end-users such as:

- - organisations, monument authorities or monument owners involved in planning and decision of monument preservation policies and strategies,

- - contractors involved in damage diagnosis and carrying out monument preservation activities like architects, engineers, restorers, conservators, consultants, project managers and construction companies.

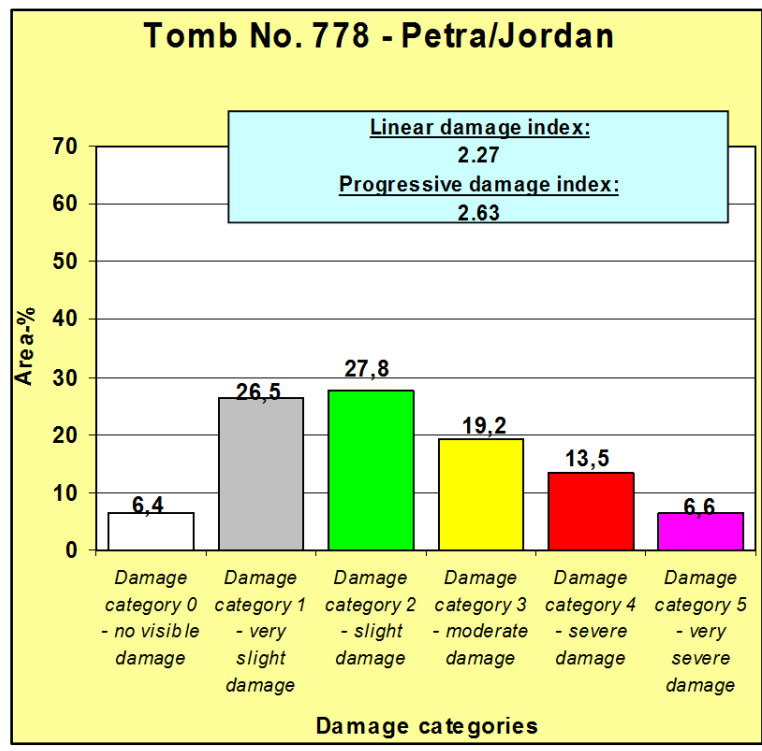

Figure 17. Quantitative evaluation of damage categories and damage indices, Tomb No. 778, Petra (Jordan).

\subsection{In situ measurements}

In situ measurements provide complementary quantitative information on stone materials and weathering characteristics. They enable examination of stone structures without any changes due to sampling or removal. During the last decades different measuring methods have been developed, often adapted from other disciplines and modified for application at stone monuments.

Surface measuring, acoustic methods, electromagnetic methods, geo-electric methods, water uptake methods, strength testing methods, bore-hole methods and chemical investigation procedures can be distinguished. The mode of operation ranges from non-destructive via slightly destructive to destructive. Preferably, nondestructive procedures should be applied. Expenditure regarding equipment, working procedure and costs can vary extremely. Most of the methods allow only spot measurements and provide information for very limited local parts of stone structures. Therefore, selection of characteristic 
areas at the monument and sufficient number of measurements are required in order of reliable and representative results. In the following some suitable in situ measuring methods are described briefly.

Ultrasonic measurements represent an appropriate non-destructive acoustic method for the characterization of stone type and weathering state. Measurements according to the transmission mode can be applied successfully at natural stone monuments, especially at columns, pillars, pilasters, slabs or sculptural decoration. Ultrasonic velocities are calculated from transit time and measuring distance. Ultrasonic measurements are used for the supplementation, verification and quantification of results obtained from phenomenological studies The geometry of fissures and premacroscopic stone degradation like microcracks can be detected. Classification schemes of ultrasonic velocities can be developed for individual stone types for rating the degree of damage. Ultrasonic measurements are very suitable for long-term monitoring of stone structures and they can also be applied successfully for rating the effectiveness of stone treatment measures. Ultrasonic tomography for stone structures is a modern scientific concern. Results of ultrasonic measurements are shown for the Lion horoscope of the famous Nemrut Dag in Turkey (Figures 18 and 19). In the map of ultrasonic velocities (Figure 19) the transition from high ultrasonic velocities (green) to low ultrasonic velocities (red) corresponds to increasing stone degradation.

The infrared-thermography represents an electromagnetic method. The heat-induced infrared radiation of stone materials is registered. Temperature gradients along a surface are detected. Measurements of surface temperatures are possible even for larger monument structures. The results on the temperature behaviour of the stone materials contributes to information on stone types, weathering state and exposition characteristics. Weathering damage can be detected by means of temperature anomalies. The results obtained from infrared-thermography can also indicate surface areas which are affected by high humidity load.

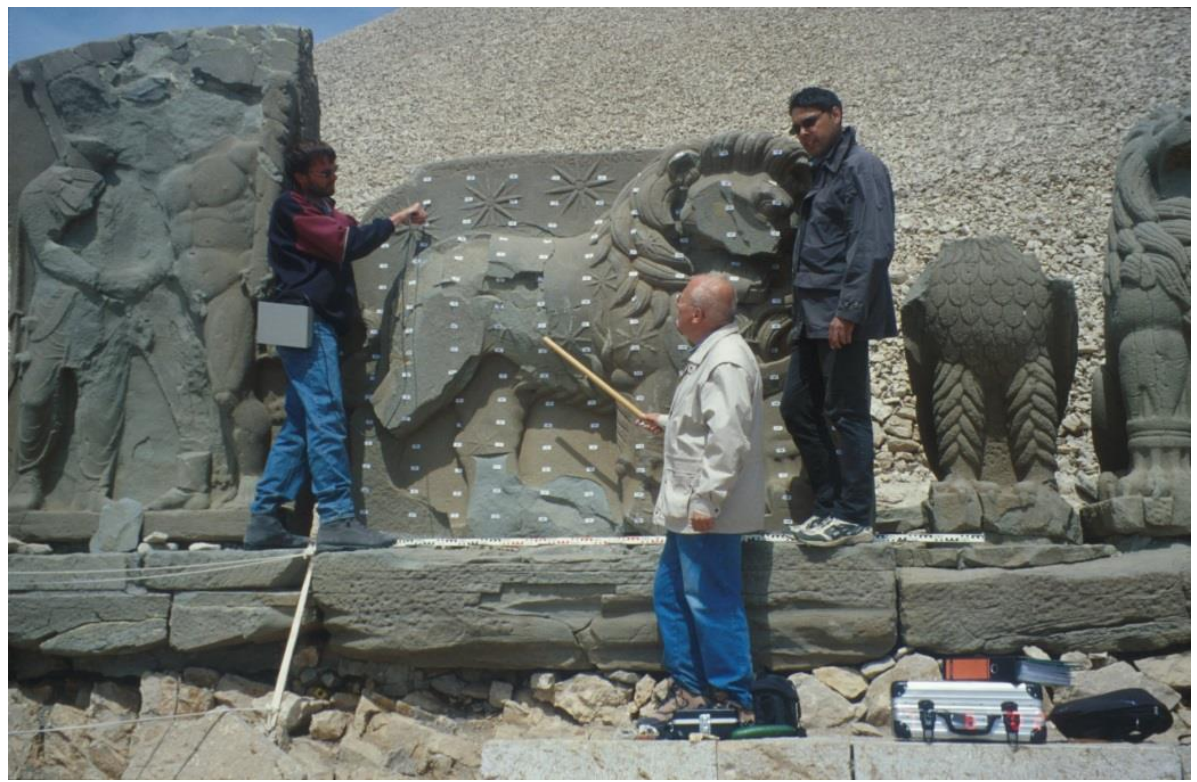

Figure 18. Ultrasonic measurements, lion horoscope / Nemrut Dag (Turkey).
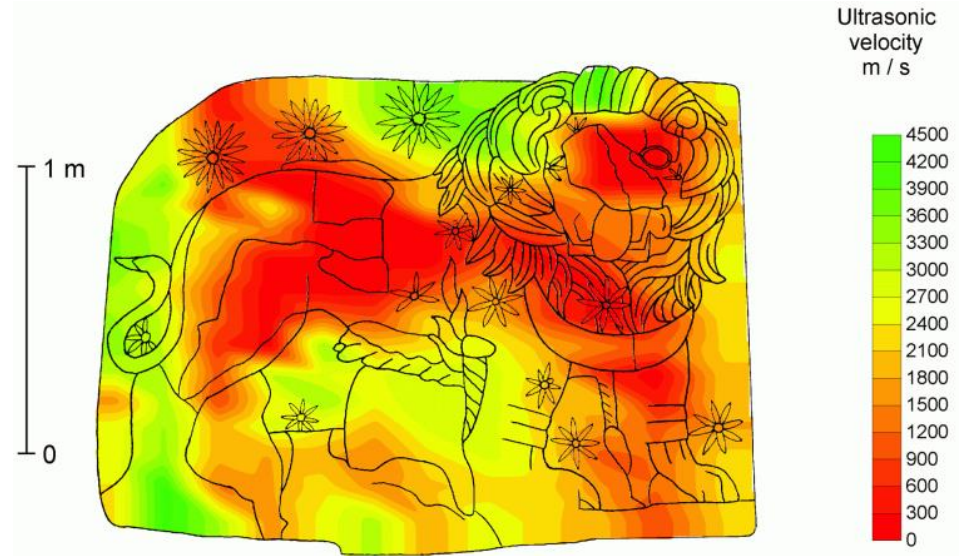

Figure 19. Map of ultrasonic velocities, lion horoscope / Nemrut Dag (Turkey). 
Water uptake measurements are carried out for the quantification of capillary water uptake and water penetration depth and for the characterization of water migration. Additionally, the results provide information on porosity properties and surface condition of the building materials. Stone types and weathering states can be characterized and compared. A simple nondestructive method used very frequently for water uptake measurements is the KARSTEN tube method (Figure 20). Water uptake measurements are also very suitable for studies on the effectiveness of treatments with water repellents.

Drilling resistance measurements and rebound hardness measurements are often applied in situ for the measuring of mechanical stone properties. Drilling resistance measurements represent a modern, only slightly destructive method which registers drilling depth versus drilling time (Figure 21). The drilling with portable drilling equipment is performed with constant pressure, energy supply and rotation speed. The drilling resistance - also called drilling hardness - as indicator for stone strength is calculated. Profiles are obtained characterizing drilling resistance versus drilling depth. Results gained from drilling resistance measurements guarantee quantitative information for comparison of stone types, characterization of weathering profiles and correlation between weathering forms and weathering profiles. Additionally, drilling powder can be collected for laboratory analyses.

Rebound hardness measurements with the SCHMIDT Test Hammer represent a quite popular in situ method for the measuring of mechanical stone properties (Figure 22). A plunger strikes the stone surface. The mass then tends to rebound. Degree of rebound correlates to the energy absorption, which depends upon the stone hardness. The results allow the characterization and comparison of stone types as well as quantitative information on state of degradation. Attempts have been made to correlate stone hardness and strength properties.

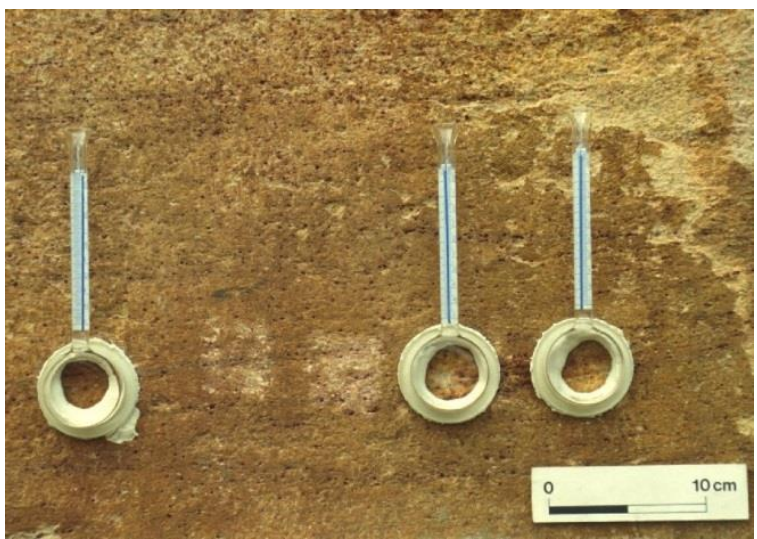

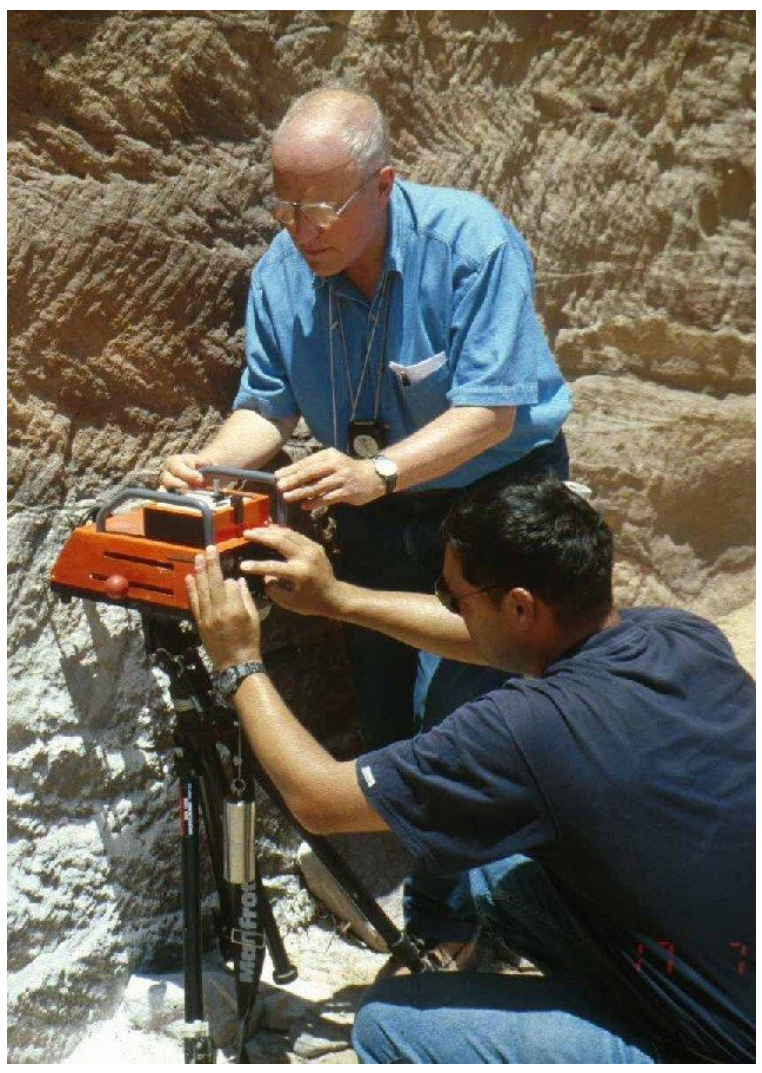

Figure 21. Drilling resistance measurements.

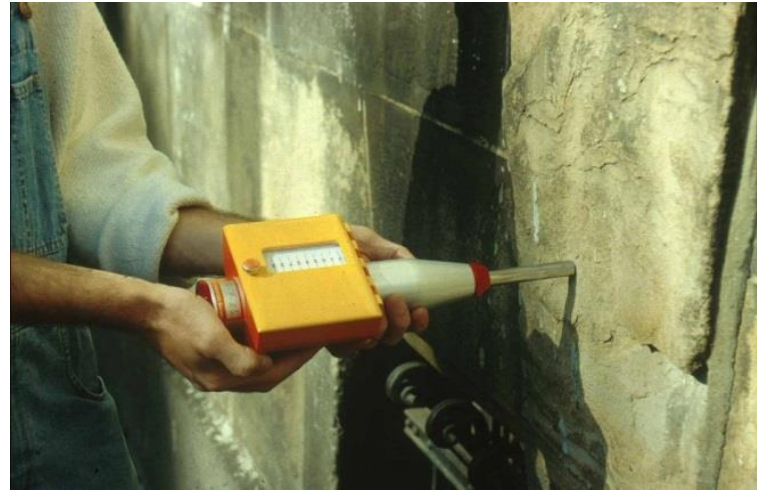

Figure 22. Rebound hardness measurements, Schmidt hammer.

\subsection{Sampling}

In the frame of comprehensive diagnosis, samples of unweathered, weathered and treated stone material are necessary for laboratory studies in order of:

- characterization and classification of stone materials,

- characterization, quantification and rating of stone alteration,

- identification and quantification of weathering products,

- rating of stone quality,

- characterization and rating of effectiveness of stone treatment.

Figure 20. Water uptake measurements with Karsten tubes. 
Unweathered stone material for laboratory analyses, weathering simulation or outdoor exposure should be taken from relevant quarries. Sampling of weathered or treated stone material at monuments must be performed most carefully. Number and quantity of samples have to ensure that the scientific and practical problems can be approached systematically and can be solved satisfactory. Today, many analytical techniques need only small amounts of stone material. Based on results obtained from the preceding in situ investigation, representative sampling can be welldirected and can be reduced to necessary extent. Precise documentation of sampling is required.

\section{LABORATORY STUDIES}

The geological history has resulted in a variety of stone types with remarkably different stone properties. All stones used as construction material are affected by naturally or anthropogenically induced weathering processes. The weathering processes evoke again changes of the stone properties. These modifications due to weathering represent an important part of comprehensive diagnosis and they are essential for effective monument preservation measures.

The stone properties such as macroscopic characteristics, mineral composition, geochemical composition, microtexture, porosity properties, hygric properties, mechanical properties and thermal properties are studied by means of modern analytical procedures. Composition and spatialgeometrical configuration of the components represent the basic stone characteristics which control the hygric, mechanical or thermal properties. Different methods have been developed for stone analysis. It is very important, to select appropriate methods or suitable combinations of methods to ensure an efficient approach to the scientific and practical goals of monument preservation.

The first step of analysis comprises the documentation and description of the stone material according to macroscopic criteria such as colour, gloss, discernible mineral components and macrotextural / -structural features. Colour charts (e.g. MUNSELL colour chart) are used for the objective definition of stone colour. Detailed information on specification and measurement of colour is presented in (FITZNER, 1994). Standard tools like hand lens or binocular microscope are used for the description of macrotextural/-structural features. Based on their macroscopical characteristics, stones can be assigned to stone groups.

The X-ray diffraction analysis (XDA) represents the classical procedure for detection of mineral components and it is the most efficient method for the identification of clay minerals and salts. Only small samples are needed for the analysis. This means another considerable advantage of this method.

Thin section microscopy is applied as standard method for the quantification of the mineral composition. Based on their modal composition, stones are classified according to well-established petrographical classification schemes. Furthermore, mineral alteration, dissolution or decomposition and neogenic mineral formation due to weathering are described.

The geochemical composition contributes to the classification of stones and to the description and quantification of stone alteration. Geochemical data are needed for the elucidation of lithogenesis. Attempts have been made to use geochemical data as "fingerprints" for the identification or verification of the provenance of natural stones and environmental factors like pollutants, salts or organic components. X-ray fluorescence spectroscopy (XRF), microprobe, atomic absorption spectroscopy (AAS) and atomic emission spectroscopy (AES) are methods for the exact determination of geochemical composition. Salts are analysed by means of ion chromatography (IC) and photometric methods.

Microtextural properties control the weathering behaviour and durability of natural stones. Shape, sizes, contacts, arrangement / orientation and recrystallization, intergrowth / overgrowth of components as well as heterogeneities, anisotropies, interfaces or micromorphology are parameters characterizing the microtexture. Stone genesis and susceptibility of the stone material to weathering can be inferred from these characteristics. Optical microscopy in combination with image analysing systems and scanning electron microscopy (SEM) represent the traditional methods for microtextural studies. Microtomography, ultrasonic measurements, roughness measurements or laseroptical measurements can be applied as complementary procedures for assessment of microtexture.

Porosity properties decisively control quality and weathering behaviour of natural stones. Physical, chemical and biological weathering processes mainly take place in the pore space and modify the porosity characteristics. Knowledge of porosity characteristics like total porosity, pore sizes, pore size distribution and pore surface is essential for:

- stone characterization,

- modelling of transportation processes regarding gaseous and liquid phases, 
- assessment of stone durability,

- interpretation and prediction of the weathering behaviour,

- quantification and rating of stone deterioration,

- evaluation of effectiveness of stone treatments.

Experience has shown that the complex porosity properties cannot be determined by one analytical procedure. Only the joint application of direct and indirect procedures can guarantee a reliable and realistic characterization of porosity properties (FITZNER, 1994; BORELLI, 1999). Four complementary methods for joint assessment of porosity properties are briefly described in the following. Thin section microscopy and scanning electron microscopy represent methods which allow direct documentation and measuring of pore space. Mercury porosimetry and nitrogen sorption method are indirect procedures. Most of the indirect methods measure the intrusion and extrusion behaviour of liquid phases in the pore space (e.g. mercury porosimetry) or the sorption of gases at the surface of pores (e.g. nitrogen sorption method). Porosity data then are calculated from the measuring results.

The microscopic analysis of thin sections represents the traditional direct method for porosity investigation. The additional use of image analysis has improved statistical evaluation of porosity, pore sizes and pore shapes. With respect to measuring by means of image analysis, visibility of pore space is required. This can be achieved by the impregnation of the stone material with coloured or UVfluorescent resin. Images of a standard thin section and an impregnated thin section under UV-light are presented for the marble of the Lion fountain in the Alhambra, Granada / Spain (Figures 23 - 25). In Figure 25 the pore space - marked by yellow colour - indicates the early phase of granular disintegration.

Porosity studies with a resolution limit up to $0.001 \mu \mathrm{m}$ are possible by means of scanning electron microscopy. The geometry and spatial distribution of pores can be precisely described, whereas statistical information on porosity characteristics is limited due to high magnification and correspondingly very small sections of the samples.

Mercury porosimetry represents the most frequently applied indirect measuring method for porosity studies. With this method - contrary to all other measuring procedures - almost the whole range of pore sizes occurring in stones can be studied. According to the principle of mercury intrusion in dependence on pressure, pores with radii in the range of $0.0019 \mu \mathrm{m}$ up to $200 \mu \mathrm{m}$ can be measured. Based on proportionality between pressure for mercury intrusion and the dimension of the pores, the measuring results allow the calculation of total porosity, densities, median pore radius, pore size distribution and pore surface.

Pore surface area, pore volume and pore radii distribution in the measuring range of $0.001 \mu \mathrm{m}$ to $0.1 \mu \mathrm{m}$ can be determined by means of the nitrogenadsorption method. These porosity data are calculated from quantity of gas isothermally adsorbed by the porous material. This method has turned out to provide best results on micropores.

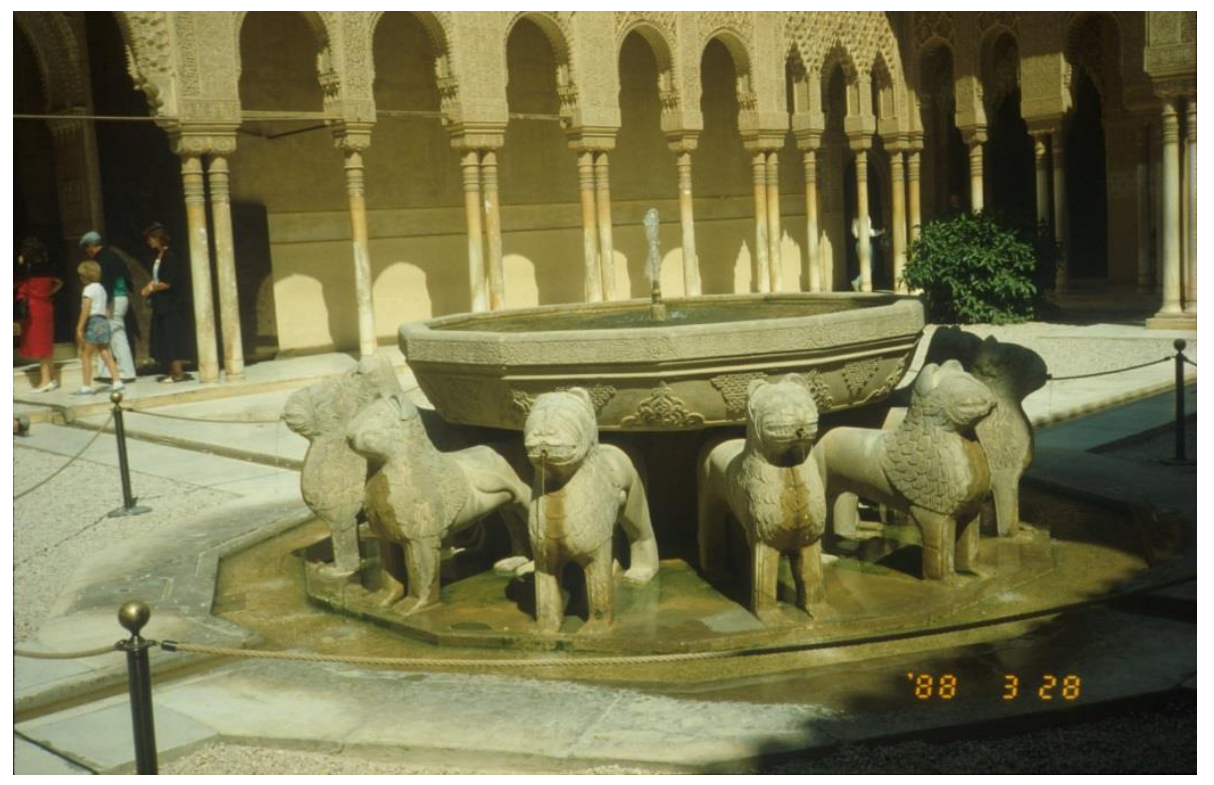

Figure 23. Lion fountain, Alhambra / Granada (Spain). 


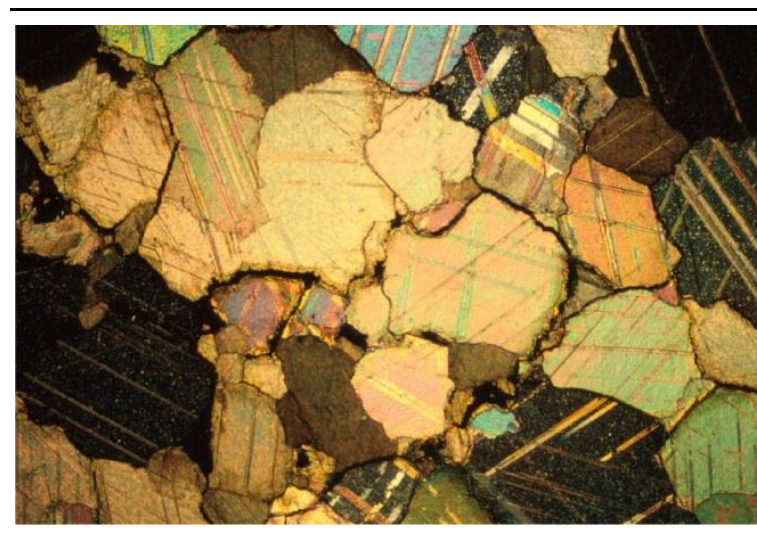

Figure 24. Thin section, marble. Lion fountain, Alhambra / Granada (Spain).

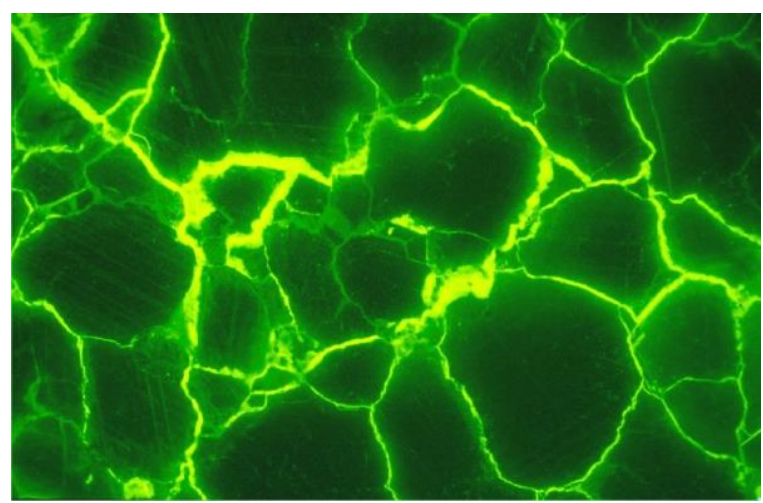

Figure 25. Impregnated thin section, marble, UV-light. Yellow areas mark the pore space. Lion fountain, Alhambra / Granada (Spain).

Measuring ranges of thin section microscopy / image analysis, scanning electron microscopy, mercury porosimetry and nitrogen sorption method are different, but the joint evaluation of results obtained from the four methods allow to derive realistic pore models of natural stones.

Weathering processes are associated with water. Water absorption and desorption, water transport and migration and hygric dilatation of natural stones are hygric processes. The hygric properties of natural stones are conditioned by their porosity characteristics. Hygric properties are considered for the characterization of stone materials and their state of weathering as well as for stone treatment and the design of protective agents.

National and international norms are wellestablished for studies on hygric properties such as water absorption / desorption, saturation coefficient, water permeability, hygroscopic capacity, isothermal water vapour absorption or water vapour permeability. Hygric shrinking / swelling of natural stones is measured by means of dilatometer, extension gauge or other length variation measuring devices.

Stone weathering is associated with decrease of strength / hardness due to granular disintegration, loss of cohesion or cracks. Strength / hardness and deformation properties additionally facilitates stone characterization and quantification of stone deterioration. The integration of results on mechanical properties enhances stone life cycle analysis and the appraisal of stone durability as well as the deduction of models regarding the weathering behaviour of natural stones.

Most of the standardized strength testing procedures are destructive. They require larger amounts of stone material and larger-sized samples. Alternatively, non-destructive or only slightly destructive procedures like ultrasonic measurements, various types of hardness measurements and drilling resistance measurements can provide results used as indicators of strength. These alternative procedures are very suitable for investigation of historical construction materials.

Temperature as weathering factor and the responses and proneness of the stone material to temperature variation are characterized by thermal analysis. Hot plate and hot box procedure, dilatometer, extension gauge or other length variation measuring devices are used to determine the properties such as thermal conductivity, heat capacity, thermal resistance or thermal dilatation.

\section{WEATHERING SIMULATION AND OUTDOOR EXPOSURE}

The priority aim of accelerated weathering simulation tests and outdoor exposure studies is the elucidation of deterioration mechanisms and processes (MIRWALD \& BRÜGGERHOFF, 1997). They contribute to:

- - development of weathering models,

- characterization and quantification of weathering progression,

- - appraisal of stone quality / durability,

- - selection of appropriate natural stones for stone replacement measures,

- - rating of effectiveness of stone treatment.

The great advantage of weathering simulation tests and outdoor exposure studies is the possibility of comparing various materials under identical conditions (FITZNER \& KALDE, 1991). In all types of experiments thorough characterization of initial stone properties, quantification of the external factors and monitoring of any change / alteration of the stone material are required as basis for reliable interpretation of results.

Compared to outdoor exposure studies, weathering simulation tests in chambers (Figures 26 and 27) have the advantage of time reduction and controlling of factors. Norms for standardized 
simulation tests have been elaborated by national and international institutions (RILEM, DIN, ASTM, VDI, NORMAL).

The complex interaction and synergistic effects of natural weathering factors are difficult to be considered by means of accelerated weathering simulation tests, however, the correlation of experimental results with weathering phenomena observed at monuments allow to identify and characterize the predominant factors and processes controlling the stone deterioration. Accelerated weathering simulation tests represent an important tool for research on weathering processes. They are also very suitable for the rating of stone durability and effectiveness of stone treatment (Figures 28 and 29).

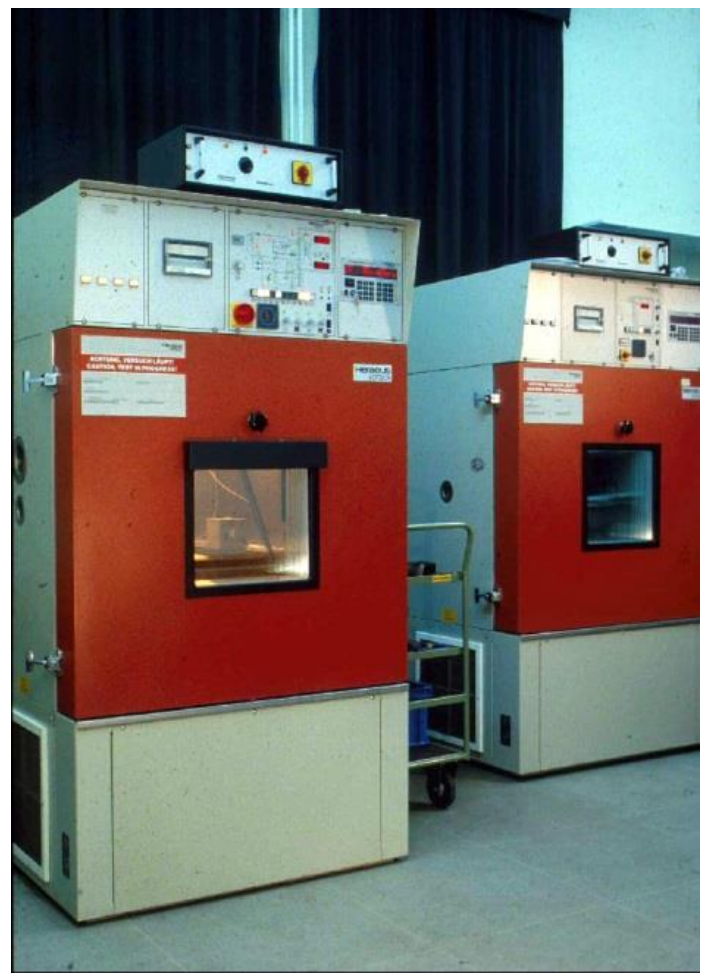

Figure 26. Weathering simulation chambers.

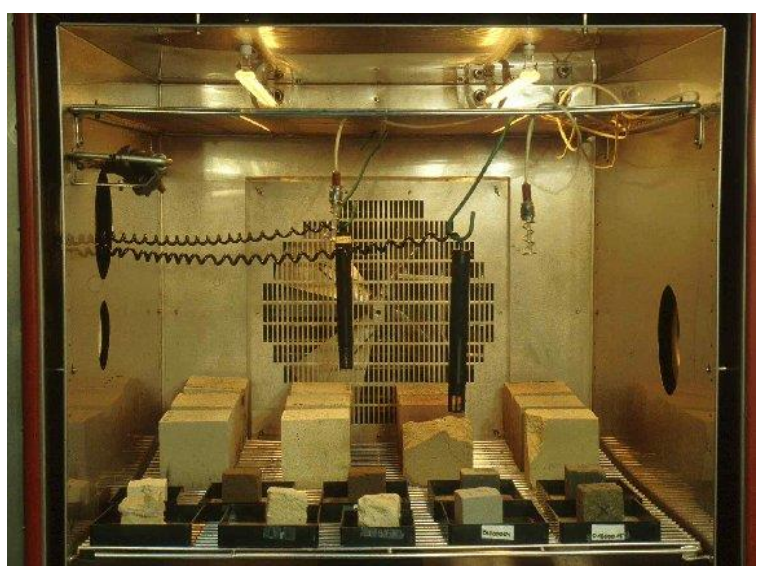

Figure 27. Weathering simulation test.

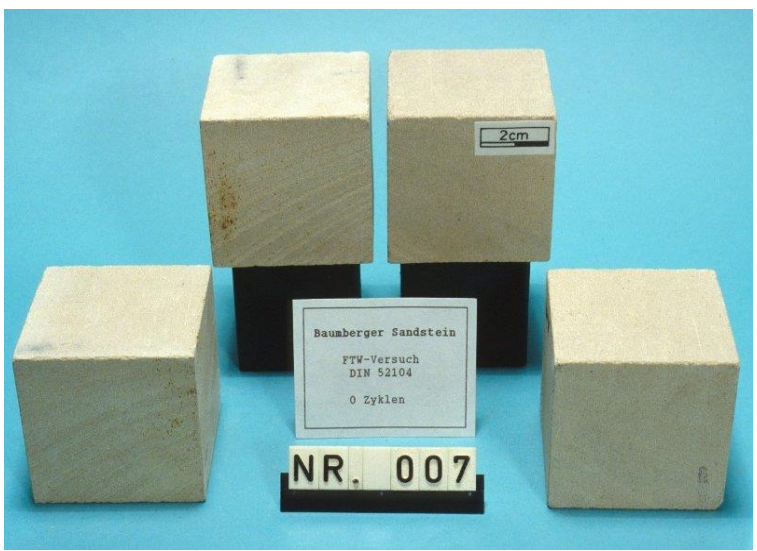

Figure 28. Weathering simulation. Baumberg sandstone (Germany), unweathered.

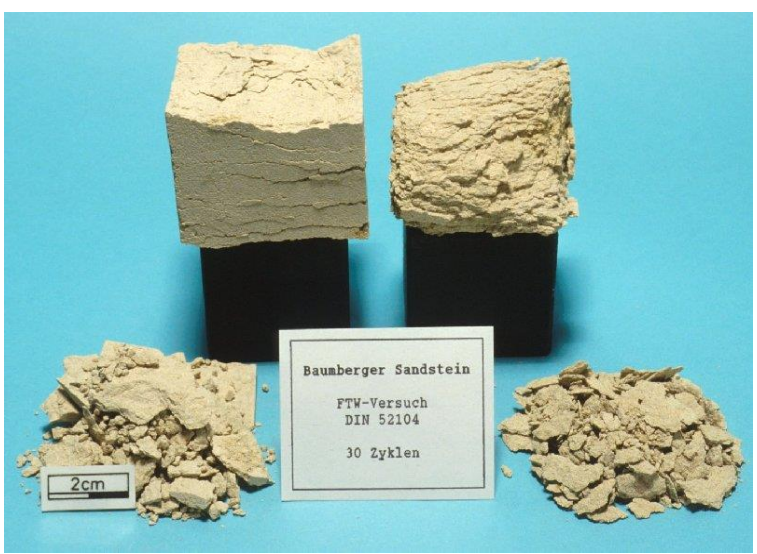

Figure 29. Weathering simulation. Baumberg sandstone (Germany), after 30 freeze-thaw cycles.

Outdoor exposure tests represent long-term studies. Stone samples are exposed to the climatic elements and environmental factors (Figure 30).

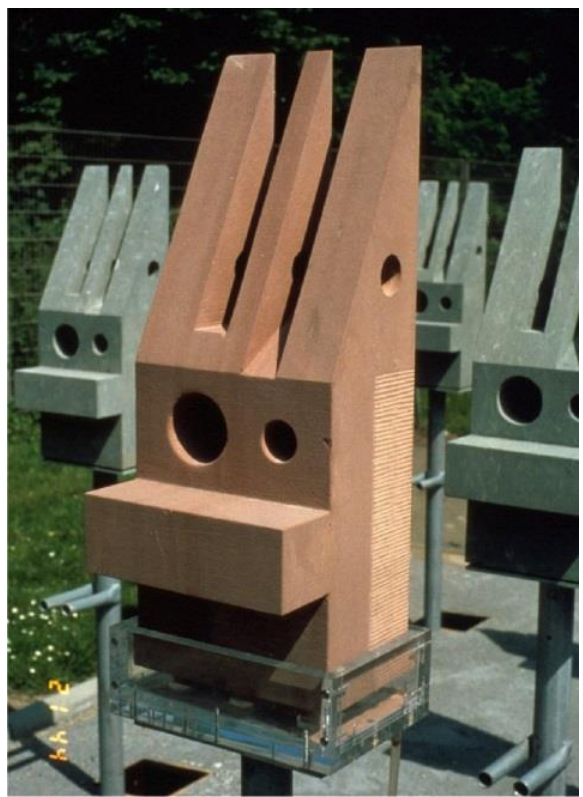

Figure 30. Outdoor exposure test, Duisburg (Germany). Sample shape considers different exposure characteristics occurring on monuments. 
Outdoor exposure tests contribute to following scientific and practical aims:

- - differentiated and quantitative assessment of weathering mechanisms and processes, weathering phenomena and state of stone deterioration in dependence upon stone types, weathering factors and time,

- - identification of critical threshold levels with respect to stone properties and environmental influences,

- - quantification and explanation of initial, premacroscopic and early phases of stone deterioration,

- - rating of effectiveness of stone treatment,

- elaboration of monument preservation strategies.

\section{CONCLUSIONS}

Precise damage diagnosis is required for the characterization, interpretation, rating and prediction of weathering damage on stone monuments and is vital for sustainable monument preservation. The monument mapping method has been developed as a modern scientific procedure for in situ studies and evaluation of weathering damage. The mapping method ensures a modern contribution to comprehensive and reliable damage diagnosis. It has met great international acceptance and has been applied successfully on numerous monuments worldwide. The consequent use of weathering forms, damage categories and damage indices means a consistent strategy for the characterization, quantitative evaluation and rating of weathering damage on stone monuments as well as a basis for the deduction of appropriate and economic monument preservation measures. The evaluation of weathering damage is based on lithological mapping and mapping of weathering forms. A detailed classification scheme of weathering forms has been developed as prerequisite for the objective and reproducible description and registration of weathering phenomena. Damage categories have been established for the rating of individual damage. Damage indices have been introduced as very practical tool for the conclusive quantification and rating of weathering damage on stone monuments. With respect to monument preservation practice, the results obtained from monument mapping represent a contribution to deduction, testapplication and execution of efficient and economic monument preservation measures. The mapping method ensures a high benefit-cost ratio. Costs for the in situ studies and the evaluation of results amorthize from effective and economic preservation measures. The consequent use of weathering forms, damage categories and damage indices means also a very suitable strategy for the control / certification of preservation measures and for the regular reevaluation of monuments in the framework of longterm survey and maintenance of monuments.

In situ measurements provide complementary quantitative information on stone materials and weathering characteristics. They allow the examination of stone structures without any changes due to sampling or removal.

In the framework of comprehensive damage diagnosis, samples of unweathered, weathered and treated stone material are needed for laboratory analyses, weathering simulation and outdoor exposure tests. Based on the preceding in situ investigation, sampling can be well-directed and can be reduced to necessary extent.

Stone properties such as visual characteristics, mineral composition, geochemical composition, microtexture, porosity properties, hygric properties, mechanical properties and thermal properties are studied by means of modern analytical procedures. Different methods have been developed for these stone analyses. Knowledge of stone properties is essential for the characterization and rating of stone materials and their weathering behaviour.

Weathering simulation tests and outdoor exposure studies contribute to the development of weathering models, the characterization and quantification of weathering progression, the appraisal of stone quality / durability, the selection of appropriate natural stones for stone replacement and the rating of effectiveness of stone treatments.

The consistent evaluation strategy based on in situ investigation and laboratory studies can be recommended to organisations, monument authorities and monument owners involved in planning and decision making of monument preservation policies and strategies as well as to architects, engineers, restorers, conservators, consultants, project managers or companies involved in damage diagnosis and monument preservation activities.

\section{REFERENCES}

ASHURST, J. \& ASHURST, N. (1988). Stone masonry.- Practical Building Conservation. English Heritage Technical Handbook, Vol. 1, Gower Technical Press, England.

BORELLI, E. (1999): Porosity.- Conservation of Architectural Heritage - Historic Structures and Materials, ARC Laboratory Handbook, ICCROM, Rome, Italy.

CROCI, G. (1998): The conservation and structural restoration of architectural heritage.- Advances in Architecture Series, Computational Mechanics Publications, Southampton, United Kingdom. 
FITZNER, B., HEINRICHS, K. \& VOLKER, M. (1997): Model for salt weathering at Maltese Globigerina limestones.- In Zezza, F. (ed.): Proceedings of the E.C. Research Workshop "Origin, mechanisms and effects of salts on degradation of monuments in marine and continental environment", March 25-27, 1996, Bari (Italy), 333-344, C.U.M. University School of Monument Conservation, Bari.

FITZNER. B. \& HEINRICHS, K. (1998): Damage diagnosis at natural stone monuments - mapping and measurements.Proceedings of the $4^{\text {th }}$ International Congress on Restoration of Buildings and Architectural Heritage, La Habana -Cuba, 13.17.07.1998: 170-172, Centro Internacional para la Conservación del Patrimonio, CICOP, Spain.

FITZNER. B. \& HEINRICHS, K. (1998): Evaluation of the weathering state of natural stones by monument mapping.- In Sulovsky, P. \& Zeman, J. (ed.): Proceedings of the conference ENVIWEATH 96 "Environmental aspects of weathering processes", Brno-Czech Republic, 1-3 December 1996: 55-64, Brno/Czech Republic.

FITZNER, B., HEINRICHS, K. \& KOWNATZKI, R. (1995): Weathering forms - classification and mapping. Verwitterungsformen Klassifizierung und Kartierung.- In: Denkmalpflege und Naturwissenschaft, Natursteinkonservierung I: 41-88, Förderprojekt des Bundesministeriums für Bildung, Wissenschaft, Forschung und Technologie, Verlag Ernst \& Sohn, Berlin.

FITZNER, B., HEINRICHS, K. \& KOWNATZKI, R. (1997): Weathering forms at natural stone monuments - classification, mapping and evaluation.- International Journal for Restoration of Buildings and Monuments, Vol. 3, No. 2: 105-124, Aedificatio Verlag, Freiburg / Fraunhofer IRB Verlag, Stuttgart.

FITZNER, B., HEINRICHS, K. \& VOLKER, M. (1997): Monument mapping - a contribution to monument preservation.- In Zezza, F. (ed.): Proceedings of the E.C. Research Workshop "Origin, mechanisms and effects of salts on degradation of monuments in marine and continental environment", March 25-27, 1996, Bari (Italy), 347-355, C.U.M. University School of Monument Conservation, Bari.

FITZNER, B. \& KOWNATZKI, R. (1997): Erfahrungen mit der Kartierung von Verwitterungsformen an Natursteinbauwerken. - In: Leschnik, W. \& Venzmer, H. (ed.): Bauwerksdiagnostik und Qualitätsbewertung, WTASchriftenreihe, Heft 13, 157-172, Aedificatio Verlag, Freiburg / Fraunhofer IRB Verlag, Stuttgart.

FITZNER. B. \& HEINRICHS, K. (2002): Damage diagnosis on stone monuments - weathering forms, damage categories and damage indices.- In Prikryl, R. \& Viles, H.A. (ed.): Understanding and managing stone decay, Proceedings of the International Conference "Stone weathering and atmospheric pollution network (SWAPNET)", May 7-11, 2001, Prachov Rocks - Czech Republic, Karolinum Press, Charles University, Prague.

FITZNER, B., HEINRICHS, K. \& LA BOUCHARDIERE, D. (2002): Damage index for stone monuments.- In Galan, E. \& Zezza, F. (ed.): Protection and conservation of the cultural heritage of the Mediterranean cities, Proceedings of the $5^{\text {th }}$ International Symposium on the Conservation of Monuments in the Mediterranean Basin, Sevilla, Spain, 5-8 April 2000: 315-326, Swets \& Zeitlinger, Lisse, Netherlands.

FITZNER, B. (1994): Porosity properties and weathering behaviour of natural stones - methodology and examples.- Proceedings of the C.U.M. $2^{\text {nd }}$ Course "Stone materials in monuments: diagnosis and conservation", Crete (Greece), 24.-30.05.1993: 43-54, Community of Mediterranean Universities C.U.M., University School of Monument Conservation, Bari (Italy).

FITZNER, B. \& KALDE, M. (1991): Simulation of frost-thaw cycle and salt weathering - nature adapted material tests.- In
Auger, F. (ed.): Proceedings of the International Symposium "The Deterioration of Building Materials", La Rochelle, 12-14 June 1991: 103-114, Laboratoire de Construction Civile et Maritime, Université de Poitiers - I.U.T., La Rochelle, France.

FITZNER, B: \& HEINRICHS, K. (2004): Photo atlas of weathering forms on stone monuments. www.stone.rwth-aachen.de

HEINRICHS, K. \& FITZNER, B. (1999): Comprehensive characterization and rating of weathering state at monuments carved from bedrocks in Petra/Jordan weathering forms, damage categories and damage index. Annual of the Department of Antiquities of Jordan, XLIII: 321351, Amman.

HEINRICHS, K. \& FITZNER, B. (2000): Deterioration of rock monuments in Petra/Jordan.- Proceedings of the 9th International Congress of the Deterioration and Conservation of Stone, 19-24 June 2000, Venice - Italy, Volume 2: 53-61, Elsevier, Amsterdam.

KOWNATZKI, R. (1997): Verwitterungszustandserfassung von Natursteinbauwerken unter besonderer Berücksichtigung phänomenologischer Verfahren.- Dissertation RWTH Aachen, Aachener Geowissenschaftliche Beiträge, Bd. 22, Verlag der Augustinus Buchhandlung, Aachen.

NAPPI, A. \& CÔTE, P. (1997): Non-destructive test methods applicable to historic stone structures.- In Baer, N. S. \& Snethlage, R. (ed.): Report of the Dahlem Workshop on "Saving our architectural heritage: The conservation of historic stone structures", Berlin, March 3-8, 1996: 151-166, John Wiley \& Sons Ltd.

MIRWALD, P. W. \& BRÜGGERHOFF, S. (1997): Requirements for and interpretation of accelerated and field testing.- In Baer, N. S. \& Snethlage, R. (ed.): Report of the Dahlem Workshop on "Saving our architectural heritage: The conservation of historic stone structures", Berlin, March 3-8, 1996: 255-268, John Wiley \& Sons Ltd.

PETZET, M. (1999): Principles of monument conservation.ICOMOS Journals of the German National Committee, XXX, Lipp Verlag, München.

PRICE, C. A. (1996): Stone conservation - an overview of current research.- Research in Conservation Series, Getty Conservation Institute, USA

URLAND, A. (1999): Colour - specification and measurement.Conservation of Architectural Heritage - Historic Structures and Materials, ARC Laboratory Handbook, ICCROM, Rome, Italy.

VILES, H. A., CAMUFFO, D., FITZ, S., FITZNER, B. LINDQVIST, O., LIVINGSTON, R. A., MARAVELLAKI, P. V., SABBIONI, C. \& WARSCHEID, T. (1997): Group report: What is the state of our knowledge of the mechanisms of deterioration and how good are our estimations of rates of deterioration?- In Baer, N. S. \& Snethlage, R. (ed.): Report of the Dahlem Workshop on "Saving our architectural heritage: The conservation of historic stone structures", Berlin, March 3-8, 1996: 95-112, John Wiley \& Sons Ltd.

Contribuição ao

1․ Simpósio Brasileiro de Caracterização e Conservação da Pedra 14 a 16 de dezembro de 2016, Congonhas - MG

É de responsabilidade da comissão editorial do Simpósio a revisão gramatical, ortográfica, de citações e referências bibliográficas. As normas de submissão podem se diferenciar das desta revista. 